Irena Chowańska

Olsztyn

\title{
Współczesna literatura białoruska w przekładach na język polski w latach 2006-2011 (na przykładzie Wydawnictwa Kolegium Europy Wschodniej im. Jana Nowaka-Jeziorańskiego)
}

Na początku naszego wieku, dzięki powstałym w Polsce pozarządowym organizacjom, fundacjom, towarzystwom oraz stowarzyszeniom ${ }^{1}$, polskojęzyczny czytelnik mógł się zapoznać z literaturą, kulturą i tradycjami narodów Europy Wschodniej. W ostatnim dziesięcioleciu szczególnie dużą aktywność w dziedzinie tłumaczeń współczesnej literatury białoruskiej na język polski przejawiło Kolegium Europy Wschodniej im. Jana Nowaka-Jeziorańskiego. Powołane w 2001 roku przez swego patrona Kolegium Europy Wschodniej oprócz działalności edukacyjnej i kulturalnej prowadzi działalność wydawniczą. Fundacja wydaje książki oraz płyty CD i DVD w różnych językach. W latach 2006-2011 w Kolegium wydano 12 książek literatury białoruskiej w przekładach na język polski.

Celem niniejszego przeglądu informacyjnego jest przedstawienie w porządku chronologicznym publikacji współczesnej literatury białoruskiej w tłumaczeniu na język polski wydanych przez to właśnie Kolegium Europy Wschodniej w latach 2006-2011. Praca nie rości prawa do pogłębionej analizy przetłumaczonych na język polski utworów.

W ramach serii wydawniczej „Biblioteka Białoruska” w latach 2006-2009 w Fundacji opublikowano 11 książek literatury białoruskiej w pol-

1 Zob. m.in.: Fundacja Borussia, Schroubek-Fundacja dla Wschodniej Europy, Fundacja Wspólnej Europy, Fundacja „Centrum Prasowe dla Krajów Europy Srodkowo-Wschodniej”, Towarzystwo Białoruskie w Krakowie, Białoruskie Stowarzyszenie im. R. Schumana, Centrum Polsko-Rosyjskiego Dialogu i Porozumienia, Kolegium Europy Wschodniej im. Jana Nowaka-Jeziorańskiego, Białoruskie Stowarzyszenie Literackie „Białowieża” i in. 
skich przekładach. Dana seria ukazuje się pod patronatem Ministra Kultury i Dziedzictwa Narodowego RP oraz we współpracy z białoruskim PEN Clubem. Publikacje niektórych tomów zrealizowano także z dotacji Gminy Wrocław oraz sfinansowano w ramach programu pomocy zagranicznej Ministerstwa Spraw Zagranicznych RP. Seria posiada jednakową szatę graficzną i logo, zaprojektowane przez Marka Stanielewicza, oraz opracowanie typograficzne wykonane przez Macieja Szłapkę. Serię wydawniczą „Biblioteka Białoruska" można nabyć nie tylko w księgarni internetowej Kolegium Europy Wschodniej im. Jana Nowaka-Jeziorańskiego ${ }^{2}$, lecz także w innych księgarniach polskich.

Otwiera serie „Biblioteka Białoruska” tom pod tytułem Gdy witaja sie dusze. Poezja i proza ${ }^{3}$ (309 stron), który ukazał się w 2006 roku. Zawiera on przekład utworów Ryhora Baradulina i Wasila Bykawa na język polski, ponadto 25 rysunków autorstwa W. Bykawa. W tomie także umieszczono pięć portretów R. Baradulina i W. Bykawa. Przekładu utworów na język polski dokonał Czesław Seniuch, znany tłumacz literatury białoruskiej, mający w swoim dorobku translatorskim m.in. utwory Maksima Bahdanowicza, Jakuba Kołasa, Janki Kupały, Łarysy Heniusz, Alesia Adamowicza, Uładzimira Karatkiewicza, Janki Bryla, Jana Czykwina, Uładzimira Arłowa i innych.

Omawiane wydanie rozpoczyna się wierszem R. Baradulina Gdy witaja się dusze oraz kserokopią rękopisu Bykawa napisanym w lutym 2000 ro$\mathrm{ku}$. W nim prozaik podejmuje rozważania na temat pisania poezji i listów Baradulina. Z kolei w Poetyckiej wymianie listów Bykaw pisze o samym poecie, ich przyjaźni szczególnie bliskiej w okresie, gdy autor „Trzeciej rakiety” przebywał w Finlandii i Niemczach.

Tom „Gdy witają się dusze” zawiera trzy rozdziały datowanych listów wierszowanych Baradulina adresowanych Bykawowi. Pierwszy rozdział „Ryhor Baradulin. Listy do Niemiec z Wuszaczy". Z podstrzesza maminej chaty składa się z dwudziestu sześciu listów. Drugi - „Listy do Niemiec z Mińska. Spod zaszklonego nieba" - zawiera osiemdziesiąt trzy korespondencje, zaś trzeci rozdział, mający nazwę „Listy do złotej Pragi z Mińska. Spod poły smętnej zawiei", liczy osiemnaście listów. W tomie na przemian z listami Baradulina zamieszczono trzy utwory Bykawa: „Bajki z życia wzięte”, „Lud pozbawiony Boga” i „Na chutorze”. Książkę zamykają rozważania Baradu-

\footnotetext{
2 Zob.: www.east24.eu, [6.06.2014; 13.10].

3 R. Baradulin, W. Bykau, Gdy witaja sie dusze. Poezja i proza, tłum. Cz. Seniuch, Wrocław 2006, 309 ss. Dalej w tekście odwołując się do tego źródła będzie podawana $\mathrm{w}$ nawiasie strona wydania.
} 
lina pod tytułem „Dorosnacć” o tym, czym jest przypowieść i jak ją należy opowiadać i czytać.

Warto zaznaczyć, że prezentowana książka była ostatnią pracą dwóch wybitnych białoruskich autorów. Jeszcze przed śmiercią Bykaw zdołał zobaczyć jej białoruskie wydanie. Należy podkreślić, że dobrym pomysłem było zamieszczenie przez wydawcę i tłumacza książki krótkiej informacji na temat życia i twórczości Baradulina oraz Bykawa. Przybliżają one polskojęzycznemu czytelnikowi sylwetki tych dwóch znakomitych współczesnych białoruskich pisarzy.

Tom drugi serii wydawniczej „Biblioteka Białoruska”, mający tytuł Święta nowego rocku ${ }^{4}$, został w całości poświęcony twórczości Andreja Chadanowicza, białoruskiego poety, tłumacza, literaturoznawcy, krytyka literackiego i eseisty. Mimo młodego wieku Chadanowicz ma już znaczne osiągnięcia w dziedzinie przekładu z języka angielskiego, francuskiego, ukraińskiego i polskiego. W jego dorobku translatorskim znajduja się poezje A. Mickiewicza, K. Gałczyńskiego, Cz. Miłosza, Z. Herberta i R. Krynickiego.

„Święta nowego rocku” to pierwszy po polsku wydany tom poezji Chadanowicza. Należy on do grona poetów młodego pokolenia literatury białoruskiej. Tłumaczyli wiersze Katarzyna Bortnowska, Leszek Engelking, Jan Maksymiuk, Adam Pomorski i Bohdan Zadura. Przekłady poprzedza słowo wstępne pióra Pawła Huella „Jechać do Mińska”. Niewątpliwie także bardzo dobrą praktyką redaktorów serii „Biblioteka Białoruska” jest publikowanie tekstów poetyckich dwujęzycznie, w brzmieniu oryginalnym i przekładzie. W ten sposób ukazały się i następne wydania tej Fundacji: „Pępek nieba. Antologia współczesnej poezji białoruskiej” ${ }^{5}$, „Nie chyliłem czoła przed mocą. Antologia poezji białoruskiej od XV do XX wieku” ${ }^{6}$, „Poczta gołębia” 7 .

Trzeci tom z serii „Biblioteka Białoruska” to książka Uładzimira Arłowa „Kochanek jej wysokości” ${ }^{8}$ (2006). Zawiera ona 15 opowiadań, esejów i nowel poświęconych m.in. tematyce historycznej Białorusi i poszukiwaniu własnej tożsamości Białorusinów. Adresowane polskiemu czytelnikowi

4 A. Chadanowicz, Święta nowego rocku, tłum. K. Bortnowska, L. Engelking, J. Maksymiuk, A. Pomorski, B. Zadura, Wrocław 2008, 124 ss. Dalej w tekście odwołując się do tego źródła będzie podawana w nawiasie strona wydania.

5 Zob.: Pępek nieba. Antologia wspótczesnej poezji białoruskiej, wybór i redakcja A. Chadanowicz, tłum. K. Bortnowska, I. Korybut-Daszkiewicz, K. Kotyńska, A. Kuzborska, K. Kwiatkowska, J. Maksymiuk,A. Pomorski, B. Zadura, Wrocław 2006, 217 ss.

6 Zob.: Nie chylitem czola przed moca. Antologia poezji białoruskiej od XV do XX wieku, red. L. Barszczeŭski, A. Pomorski, Wrocław 2008, ss. 640.

7 Zob.: U. Niaklajeu, Poczta gotębia, tłum. A. Pomorski, Wrocław 2011, 192 ss.

8 U. Arłou, Kochanek jej wysokości, tłum. J. Maksymiuk, H. Maksymiuk, K. Bondaruk, Wrocław 2006, 292 ss. 
utwory Arłowa pełne są humoru, sarkazmu, ironii, smutku oraz niepokoju z powodu bieżącej historii Białorusi. Tom jest opatrzony rysunkami znakomitego malarza i grafika Alaksieja Maraczkina.

Kolejna wydana książka Fundacji im. Jana Nowaka-Jeziorańskiego to „Pępek świata. Antologia współczesnej poezji białoruskiej”9. Zawiera ona wiersze 10 poetów należących, zdaniem redaktora tego tomu, do twórców młodego pokolenia literatury białoruskiej (Andrej Adamowicz, Michaś Bajaryn, Dżetsi (Wiera Burłak), Anatol Iwaszczanka, Hleb Łabadzienka, Maryja Martysiewicz, Walżyna Mort, Siarhiej Pryłucki, Maks Szczur i Wiktar Żybul). Warto nadmienić, że Walżyna Mort obecnie mieszka w Stanach Zjednoczonych, a Maks Szczur od wielu lat przebywa w Pradze.

W 2007 roku Kolegium Europy Wschodniej im. Jana Nowaka-Jeziorańskiego wydaje w serii „Biblioteka Białoruska” Alesia Razanawa „Leśna droga. Wersety" ${ }^{10}$, zbiór wierszy jednego z najbardziej eksperymentujących, nowatorskich poetów białoruskich. Teksty Razanawa wyróżniąją się bardzo wyszukanymi formami autorskimi, mają kulturowo-filozofujący charakter, mieszczą się na pograniczu wersetów biblijnych i ludowo-epickiej poezji. Należy zaznaczyć, że po raz pierwszy wiersze Razanawa były opublikowane w języku polskim już w 1975 roku na łamach periodyku „Regiony" 11 w przekładzie Floriana Nieuważnego. Zaś w 1997 roku wydano w formie książkowej dwa jego zbiory. Wyboru oraz tłumaczenia wierszy do pierwszej książki dokonał Jan Czykwin ${ }^{12}$, a drugiej książki, Zdobywcy ${ }^{13}$, tłumaczem był Oleg Łatyszonak.

Kolejną wydawniczą pozycją Kolegium okazał się tom esejów o nazwie „Dialogi z Bogiem” 14 (2008) białoruskiego filozofa, krytyka literackiego i publicysty Walancina Akudowicza. Tłumaczenia na język polski dokonali Halina i Jan Maksymiukowie. Warto podkreślić, że prace Akudowicza niejednokrotnie były publikowane w różnych krajach, m.in. w Rosji, na Ukrainie, w Czechach, Serbii, USA, Litwie i Polsce.

9 Pępek nieba. Antologia wspótczesnej poezji białoruskiej, wybór i redakcja A. Chadanowicz, tłum. K. Bortnowska, I. Korybut-Daszkiewicz, K. Kotyńska, A. Kuzborska, K. Kwiatkowska, J. Maksymiuk, A. Pomorski, B. Zadura, Wrocław 2006, 217 ss.

10 A. Razanau, Leśna droga. Wersety, tłum. O. Łatyszonek, J. Maksymiuk, Wrocław 2008, 312 ss.

11 Zob.: „Regiony” 1975, nr 2, s. 104-106.

12 A. Razanau, Podarunek matki chrzestnej, wybór i przekł. z białorus. Jan Czykwin, Białystok 1997, 59 ss.

13 A. Razanau, Zdobywcy, tłum. A. Łatyszonek, Białystok 1997, 46 ss.

14 W. Akudowicz, Dialogi z Bogiem, tłum. H. Maksymiuk, J. Maksymiuk, Wrocław 2008, 166 ss. 
Następna edycja wydawnicza z serii „Biblioteka Białoruska” to ogłoszony tom prozy pisarza, poety i filozofa Ihara Babkowa. Książka ukazała się pod tytułem „Interpretacja ru(i)n” $15 \mathrm{w}$ tłumaczeniu J. Maksymiuka.

Dwujęzyczny tom o nazwie "Nie chyliłem czoła przed mocą. Antologia poezji białoruskiej od XV do XX wieku" ${ }^{16}$, wydana w 2008 roku, jest wynikiem współpracy z białoruskim i polskim PEN Clubem. Składa się z dwóch części: „Z poezji dawnej i Z poezji nowoczesnej”, zawierających, oprócz utworów, informację o twórcach literatury białoruskiej w okresie od XV do końca XX wieku. Zwraca uwagę obecność w niej nazwisk poetów niegdyś niepożądanych lub objętych zakazem druku na Białorusi Radzieckiej oraz twórców tak zwanego „rozstrzelanego Odrodzenia”. Wyboru autorów i ich utworów oraz opracowania not bibliograficznych dokonali Lawon Barszczeuski, prezes białoruskiego PEN Clubu, tłumacz i publicysta, oraz Adam Pomorski, prezes polskiego PEN Clubu, tłumacz, eseista i krytyk literacki. Przekładem tekstów zamieszczonych w antologii zajęli się Katarzyna Bortnowska, Leszek Engelking, Ziemowit Fedecki, Jan Huszcza, Jan Kasprowicz, Jerzy Litwiniuk, Jan Maksymiuk, Seweryn Pollak, Jerzy Pomianowski, Adam Pomorski, Czesław Seniuch i Wiktor Woroszylski. Natomiast przekładu na język białoruski dokonali Ryhor Baradulin, Lawon Barszczeuski, Kastuś Ćwirka, Maksim Łużanin, Uładzimir Marchel, Uładzimir Niaklajeu i Alaksej Zarycki.

Dwujęzyczny tom prozy „Talent do jąkania się. Opowiadania wybrane" 17 w całości poświęcony jest twórczości Alhierda Bacharewicza, pisarza należącego do grona także młodych twórców literatury białoruskiej. Bacharewicz, urodzony w Mińsku, od kilku lat mieszkający w Hamburgu, ma w swoim twórczym dorobku cztery książki ( „Praktyczny poradnik rujnowania mias” [2002], „Barwy naturalne” [2003], „Żadnej litości dla Walentyny H. „[2006] i „Przeklęci goście stolicy” [2007]).

„Ołowiane żołnierzyki” 18 to kolejny tom wydany przez Kolegium Jana Nowaka-Jeziorańskiego. Zawiera on reportaże białoruskiej pisarki, dziennikarki i scenopisarki Swiatłany Aleksijewicz. Dopiero po 19 latach od momentu napisania przez nią powyższej książki ukazała się jej polska wersja. Tłumaczenia na język polski dokonał Leszek Wołosiuk, znany ze wcze-

15 I. Babkow, Królestwo Białoruś. Interpretacja ru(i)n, tłum. J. Maksymiuk, Wrocław 2008, 135 ss.

16 Nie chylitem czoła przed moca. Antologia poezji białoruskiej od XV do XX wieku, red. L. Barszczeŭski, A. Pomorski, Wrocław 2008, 640 ss.

17 A. Bacharewicz, Talent do jakania się. Opowiadania wybrane, tłum. K. Bortnowska, K. Kwiatkowska, M. Łucewicz-Napałkow, Wrocław 2008, 148 ss.

18 S. Aleksijewicz, Otowiane żolnierzyki, tłum. L. Wołosiuk, Wrocław 2008, 328 ss. 
śniejszych przekładów prozy Aleksijewicz („Krzyk Czarnobyla” [Warszawa 2000], „Urzeczeni śmiercią” [Warszawa 2002]). Umieszczone w tomie „Ołowiane żołnierzyki" reportaże dotyczą tematu wojny afgańskiej i jej skutków. W swoich utworach pisarka niejednokrotnie powraca do tematu wojny, odwołuje się do udziału kobiet w II wojnie światowej, wojennych losów dzieci, czarnobylskiej katastrofy i upadku komunizmu. Warto wspomnieć, iż Swiatłana Aleksijewicz jest laureatką licznych radzieckich i międzynarodowych nagród, w 2011 roku otrzymała nagrodę im. Ryszarda Kapuścińskiego za reportaż literacki, a w 2013 była nominowana do Nagrody Nobla w dziedzinie literatury. Jej twórczość jest znana w wielu krajach, m.in. we Francji, Niemczech, Stanach Zjednoczonych, Szwecji, Japonii. W Polsce wydano ponadto, oprócz wcześniej wspomnianych, „Wojna nie ma w sobie nic z kobiety" (Wołowiec 2010) i „Czarnobylska modlitwa. Kronika przyszłości" (Wołowiec 2012).

Wydany w 2009 roku tom pod tytułem „Powstawanie Białorusi”19 zamyka serię wydawniczą „Biblioteka Białoruska”. Prezentowana publikacja zawiera nowe, uzupełnione teksty artykułów publikowanych na łamach „ARCHE”, „Nasza Niwa” i „Nowa Europa” autorstwa Piotra Rudkowskiego - dominikanina, filozofa, teologa, publicysty. W pracach Rudkowskiego ujawnia się jego opozycyjny stosunek wobec obecnych władz na Białorusi. Autor próbuje w nich przedstawić swoją nową, wolną i europejską Białoruś, nawiązuje do mniejszości polskiej na Białorusi, apeluje do świadomości narodowej, do możliwości prowadzenia dialogu między władzą a opozycją oraz odwołuje się do wydarzeń z marca 2006.

Ostatnią przedstawianą tu książką wydawnictwa Kolegium Europy Wschodniej im. Jana Nowaka-Jeziorańskiego jest zbiór poezji „Poczta gołębia” ${ }^{20}$, białoruskiego poety, prozaika i działacza społeczno-politycznego Uładzimira Niaklajewa. Prezentowana publikacja została zrealizowana dzięki dofinansowaniu przez Departament Dyplomacji Publicznej i Kulturalnej Ministerstwa Spraw Zagranicznych RP. Z twórczością Niaklajewa polskojęzyczny czytelnik mógł zapoznać się z wierszami znacznie wcześniej - na łamach „Literatury Radzieckiej” (1983).

Wydaje się, że na jakiś czas twórczość poetycka Niaklajewa w roku 2010 została przesłonięta jego zaangażowaniem w politykę, kiedy to poeta energicznie włączył się do wyborów prezydenckich. Kampania społeczna „Mów prawdę!" wysunęła go na kandydata na prezydenta Białorusi. Po burzliwych wydarzeniach w okresie wyborów stał się symbolem demokratycznego

19 P. Rudkouski, Powstawanie Białorusi, tłum. J. Bernatowicz, Wrocław 2009, 240 ss.

20 U. Niaklajeu, Poczta gołębia, tłum. A. Pomorski, Wrocław 2011, 192 ss. 
oporu przeciwko reżimowi Aleksandra Łukaszenki, a zainteresowanie jego twórczością znów wzrosło.

Zatem Poczta gotębia to pierwsze w Polsce książkowe dwujęzyczne wydanie wierszy tego poety oraz „Ostatnie słowo oskarżonego Uładzimira Niaklajewa przed sądem w Miński 18 maja 2011" 21. Wiersze pochodzą z siedmiu zbiorów poezji wydanych w latach 1976-2010. Wyboru oraz tłumaczenia tekstów dokonał Adam Pomorski.

Na zakończenie należy podkreślić, że dużą zaletą książek wydanych w Kolegium Europy Wschodniej jest zamieszczanie w nich not bibliograficznych o autorach. Jednak niektóre tomy z tej serii grzeszą błędami translatorskimi i technicznymi niedociągnięciami. Zastrzeżenia dotyczą napisania niektórych nazwisk. Aż w 12 książkach zauważa się brak jednolitości co do ich napisania. Otóż w tomie „Kochanek jej wysokości” imię i nazwisko autora przedstawiono w sposób następujący - Uładzimier Arłou. Z kolei w „Nie chyliłem czoła przed mocą. Antologia poezji białoruskiej od XV do XX wieku" ten sam autor występuje jako Uładzimin Arłoŭ. Dotyczy to także nazwisk: Barszczeuski, Niaklajeu, Razanau, Brouka, Babkou, gdzie litera $\mathbf{u}$ zostaje zamieniona na $\breve{\mathbf{u}}$. Wspomniana antologia „Nie chyliłem czoła przed mocą" zawiera inne uchybienia, które ujawniają się na samym początku książki. Otóż zamieszczony na okładce tytuł różni się od występującego na stronie tytułowej. Zamiast „Nie chyliłem czoła przed mocą" pojawia się "Nie chyliłem karku przed mocą”. W „Gdy witają się dusze” znajdują się także nieliczne luki w numeracji stron, zob. np. 239, 302, 304, 305 i 306.

Również poziom tłumaczenia w prezentowanych wydaniach Fundacji pozostawia wiele do życzenia, budzi wątpliwości co do jego poprawności. Błędy w tłumaczeniu pojawiają się zapewne z powodu pośpiechu samych tłumaczy, braku wnikliwej korektury, lecz również, jak się wydaje, z nienajlepszej znajomości języka oryginału i mentalności białoruskiej.

Na podstawie krótkiego przeglądu książek białoruskich pisarzy wydanych przez Kolegium Europy Wschodniej im. Jana Nowaka-Jeziorańskiego można zauważyć znaczące zainteresowanie Wydawnictwa problemami i przedstawicielami białoruskiego procesu literackiego. W centrum uwagi znalazła się zarówno poezja, jak i proza, autorzy różnych pokoleń, publikowani na Białorusi, jak i po za jej granicami. Wydawcy wybrali ciekawe utwory białoruskich twórców, które mogą zainteresować polskiego czytelnika oraz rozpropagować literaturę białoruską w Polsce.

21 U. Niaklajeu, Poczta gotębia, op. cit., s. 178-185. 
Pozostaje mieć nadzieję, że w najbliższej przyszłości polskojęzyczny czytelnik znów będzie mógł zapoznać się nowymi przekładami literatury białoruskiej.

\title{
РЭЗ Ю $\mathrm{ME}$
}

СУЧАСНАЯ БЕЛАРУСКАЯ ЛІТАРАТУРА Ў ПЕРАКЛАДЗЕ НА ПОЛЬСКУЮ

МОВУ Ў 2006-2011 ГГ. (НА ПРЫКЛАДЗЕ ВЫДАВЕЦТВА КАЛЕГІУМ УСХОДНЯЙ ЕЎРОПЫ ІМ. ЯНА НОВАКА-ЕЗЁРАНСКАГА)

У Польшчы існуюць розныя неўрадавыя арганізацыі, фундацыі, таварыства і суполкі. Ix мэтаю з'яўляецца таксама прамоцыя сучаснай літаратуры Цэнтральнай і Усходняй Еўропы, у тым ліку беларускай. Заснаваны Янам Новакам-Езяранскім у 2001 годзе Калегіум Усходняй Еўропы акрамя адукацыйнай і культурнай дзейнасці, вядзе выдавецкую дзейнасць. Фундацыя выдае кнігі і ЦД- и ДВД-плыты на розных мовах, таксама і на беларускай. У артыкуле прадстаўлена выдавецкая серыя кніг сучаснай беларускай літаратуры у перакладзе на польскую мову, выдадзеных Калегіумам Усходняй Еўропы імя Яна Новака-Езяранскага у $2006-2011$ гг.

Ключавыя словы: Пераклад сучаснай беларускай літаратуры на польскую мову, выдавецтва Калегіум Усходняй Еўропы ім. Яна Новака-Езяранскага.

\author{
S U M M A R Y
}

MODERN BELARUSIAN LITERATURE IN TRANSLATION INTO POLISH IN 2006-2011 (BASED ON JAN NOWAK-JEZIORAŃSKI EASTERN EUROPE COLLEGIUM PUBLISHING HOUSE)

One of the aims of many non-governmental organizations, foundations and societies in Poland is to promote modern literature of Central and Eastern Europe, including Belarusian literature. Eastern Europe Collegium founded in 2001 by Jan Nowak-Jeziorański is actively involved in education, culture and publishing. The foundation publishes the books, CDs and DVDs in various languages, including the Belarusian language. The article presents a series of Belarusian books translated into Polish published by Jan Nowak-Jeziorański Eastern Europe Collegium Publishing House in 2006-2011.

Key words: translation of modern Belarusian literature into Polish, Jan Nowak-Jeziorański Eastern Europe Collegium Publishing House. 